\title{
Pathology of a Gammabaculovirus in Its Natural Balsam Fir Sawfly (Neodiprion abietis) Host
}

\author{
Christopher J. Lucarotti, ${ }^{1,2}$ Beatrixe H. Whittome-Waygood, ${ }^{3}$ Renée Lapointe, ${ }^{4}$ \\ Benoit Morin, ${ }^{1}$ and David B. Levin ${ }^{5}$ \\ ${ }^{1}$ Natural Resources Canada, Canadian Forest Service, Atlantic Forestry Centre, P.O. Box 4000, Fredericton, NB, Canada E3C 2 G6 \\ ${ }^{2}$ Faculty of Forestry and Environmental Management, University of New Brunswick, Fredericton, NB, Canada E3B $6 C 2$ \\ ${ }^{3}$ Department of Biology, University of Victoria, Victoria, BC, Canada V8W 2 Y2 \\ ${ }^{4}$ Sylvar Technologies Inc., P.O. Box 636, Fredericton, NB, Canada E3B 5A6 \\ ${ }^{5}$ Department of Biosystems Engineering, University of Manitoba, Room E2-376 Engineering, Information and Technology Complex, \\ Winnipeg, MB, Canada R3T 5V6
}

Correspondence should be addressed to Christopher J. Lucarotti, clucarot@nrcan.gc.ca

Received 23 July 2012; Accepted 20 October 2012

Academic Editor: Claude Desplan

Copyright () 2012 Christopher J. Lucarotti et al. This is an open access article distributed under the Creative Commons Attribution License, which permits unrestricted use, distribution, and reproduction in any medium, provided the original work is properly cited.

\begin{abstract}
The Neodiprion abietis Gammabaculovirus (Baculoviridae: NeabNPV) is virulent, highly contagious, and infects only midgut epithelial cells of balsam fir sawfly larvae, but infections can carry through to adult sawflies in the midgut. Larval infections are characterized by hypertrophy of midgut epithelial cell nuclei, where virogenic stromata develop to produce nucleocapsids that are singly enveloped before occlusion into occlusion bodies. Infected, occlusion body-laden cells slough from the midgut epithelium as a result of a dissolution of the basal lamina. Infected cells undergo lysis, and viral occlusion bodies exit affected larvae in a watery diarrhea to infect other balsam fir sawfly larvae. A budded virus stage was not observed, but nucleocapsid and occlusion body formation resembled the development of occlusion-derived virions and occlusion bodies in lepidopteran alphabaculoviruses.
\end{abstract}

\section{Introduction}

The Baculoviridae are a family of covalently closed, doublestranded DNA (dsDNA) viruses that are only known to infect insects belonging to the orders Lepidoptera (virus genera: Alphabaculovirus and Betabaculovirus), Diptera (Deltabaculovirus), and Hymenoptera (Gammabaculovirus) [1, 2]. Selection pressure and a long history of coevolution with their respective hosts appear to have restricted each virus genus to a single insect order [3]. Baculoviruses are thought to have split from the sister group, nudiviruses [4-6], about 310 million years ago (mya) [2], before which a progenitor dsDNA virus would have infected insects whose origins date back $\sim 420$ mya [7-9]. The origins of holometabolous insects may date back 355 mya, with the divergence of the Hymenoptera from other holometabolous insects occurring relatively shortly thereafter $[10,11]$. From this point, the evolution of the Euhymenoptera (Apocrita and Orussidea) was monophyletic, with the superfamilies of sawflies emerging as separate branches of the lower end of this lineage prior to the adoption of parasitic and eusocial habits by euhymenopterans $[12,13]$. Larvae of the ancestral hymenopteran were likely phytophagous, a habit retained by sawflies [12]. Larval diprionid sawflies (Tenthredinoidea: Diprioninae: Diprionidae) are defoliators of conifers [14]. There are more than 50 species of sawflies in the genus Neodiprion, and many feed on important members of the Pinaceae [15]. The balsam fir sawfly (N. abietis) is indigenous to North America, where larvae feed on balsam fir (Abies balsamea), white spruce (Picea glauca), and black spruce (P. mariana) [14], although host selection, along with temporal differences in life histories, may be isolating mechanisms for a species complex that can otherwise interbreed freely [16]. Unprecedented outbreaks of balsam fir sawfly populations on the island of Newfoundland (Newfoundland and Labrador (NL), Canada) [17] have led to the development, registration, commercialization, and use 
of an N. abietis-specific Gammabaculovirus (NeabNPV) [1821]. The genome of NeabNPV has been sequenced [22], and the in vivo replication and transcription kinetics studied [23]. There is, however, a dearth of information on the pathology of sawfly NPVs in the literature, although they are thought to only infect the midgut epithelium of their hosts $[24,25]$. Recently, the histology of the larval digestive tract of healthy N. abietis has been described [26]. For these reasons and to provide a visual reference for molecular studies on Gammabaculovirus pathology, we have undertaken a study of the pathology of NeabNPV in its natural N. abietis host.

\section{Materials and Methods}

2.1. Virus Stock. Neodiprion abietis nucleopolyhedrovirus (NeabNPV) (Gammabaculovirus: Baculoviridae) was isolated from $N$. abietis larvae collected from forest stands, dominated by balsam fir (Abies balsamea), around Big Gull Pond $\left(48^{\circ} 45^{\prime} \mathrm{N}: 58^{\circ} 04^{\prime} \mathrm{W}\right)$ southwest from Corner Brook in western Newfoundland in 1997. Viral occlusion bodies (OBs) were amplified, purified, and quantified as described previously $[18,20]$.

2.2. Larval Infection, Tissue Preparation, and Analysis. Balsam fir sawfly larvae were collected from balsam fir branches at the leading edges of the balsam fir sawfly population outbreak in the Corner Brook-Deer Lake region beginning in $1999[18,26]$. Larvae on branches were maintained in 20$\mathrm{kg}$ brown paper bags at $4^{\circ} \mathrm{C}$ until the larvae were harvested, which was within $48 \mathrm{~h}$ of collection. Larval head capsules were measured using a calibrated micrometer mounted in the objective lense of a dissecting microscope [26, 27]. Third to fifth instars were selected, at random, for NeabNPV infection because of their size and ease of handling compared with first and second instars. Larvae were first starved for 12$15 \mathrm{~h}$ at ambient room temperature $\left(\sim 20^{\circ} \mathrm{C}\right)$ prior to being manually fed a $1 \mu \mathrm{L}$ droplet of NeabNPV OBs suspended in a $10 \%$ aqueous solution of pasteurized liquid honey [23]. Larvae were held, by hand, using insect forceps (Fine Science Tools, Foster City, CA, USA) and were presented the droplet at the end of a $1 \mathrm{cc}, 27 \mathrm{G} 1 / 2$ syringe and needle (Becton Dickinson, Franklin Lakes, NJ) mounted on an automicroapplicator (Burkard Manufacturing, Rickmansworth, UK). Each droplet contained approximately $1 \times 10^{4}$ OBs [23]. Control larvae were fed single $1 \mu \mathrm{L} 10 \%$ honey droplets without OBs. Larvae were individually reared on fresh, clean ( 5 min soak in $0.25 \%$ aqueous $\mathrm{NaOCl}$ followed by three $15 \mathrm{~min}$ rinses in tap water) balsam fir foliage [26]. Most control larvae were reared through until death or pupation to monitor for ambient levels of NeabNPV infection, whereas others were prepared for cytological examination at 48 and $96 \mathrm{~h}$ after feeding. Larvae fed on NeabNPV OBs were harvested at $0.5,1,2,5,8,12,18,24,36,48,60,72$, 96, and $120 \mathrm{~h}$ after inoculation (hpi). The methods for the preparation, sectioning, and viewing of Paraplast Plus (Sherwood Medical, St. Louis, Mo, USA) and epoxy (EponAraldite, Electron Microscope Sciences, Hatfield, PA, USA) embedded larval tissues have been detailed elsewhere [26]. For in situ hybridizations, NeabNPV-infected (48-72 hpi and 96-120 hpi) and uninfected control larvae were decapitated and immediately submerged in freshly prepared $4 \%$ paraformaldehyde in phosphate-buffered saline (PBS) and were fixed for $3 \mathrm{~h}$ at $20^{\circ} \mathrm{C}$. Larvae were then rinsed in three 15 min changes in PBS, dehydrated, embedded in paraplast, and sectioned [26]. Sections were placed on Superfrost Plus Gold slides (Fisher Scientific, Fair Lawn, NJ, USA), dewaxed in three $5 \mathrm{~min}$ changes in Hemo-D (Fisher Scientific), rehydrated through 2 min changes each in 100\%, 95\%, 80\%, and $50 \%$ ethanol, and followed by six 2 min rinses in $\mathrm{ddH}_{2} \mathrm{O}$, $5 \mathrm{~min}$ in $0.02 \mathrm{M} \mathrm{HCl}$, three more rinses in $\mathrm{ddH}_{2} \mathrm{O}$, and $5 \mathrm{~min}$ in $1 \mathrm{X}$ TNE (Tris-NaCl-EDTA). Sections were then covered with $5 \mu \mathrm{g} / \mathrm{mL}$ proteinase $\mathrm{K}$ in $1 \mathrm{X}$ TNE and incubated at $37^{\circ} \mathrm{C}$ for $10 \mathrm{~min}$. Slides were drained and the reaction stopped with two $5 \mathrm{~min}$ rinses in PBS. Sections were postfixed for $5 \mathrm{~min}$ in $0.4 \%$ formaldehyde in PBS, given two 5 min rinses in PBS and a 2 min rinse in $\mathrm{ddH}_{2} \mathrm{O}$. A polh probe was generated by PCR [23], and DNA random prime labeled with digitoxindUTP; color was detected with NBT/BCIP (nitro-blue tetrazolium and 5-bromo-4-chloro-3' -indolyphosphate) as per manufacturer's instructions (DIG High Prime DNA Labeling and Detection Kit, Roche, Laval, Q, Canada). Intestinal tracts were dissected from the abdomens of live adult female balsam fir sawflies that had been collected from the field as pupae and reared through to adults in the laboratory. Intestines were mounted in sterile, distilled $\mathrm{H}_{2} \mathrm{O}$ and were examined using a compound microscope. Digital electron micrograph images were imported into Scion Image software (Scion Corporation, Frederick, MD; a Windows version of $\mathrm{NIH}$ Image, National Institutes of Health, Bethesda, MD, USA). Images of sections of midgut epithelial cells were selected at random, and measurements of the surface areas of cells, microvillar borders and nuclei were made at times 0 (uninfected control), 5, 8, 12, 24, 48, and 72 hpi. Proportional ratios of microvillar border or nuclear surface area profiles against cellular surface area profiles were calculated. The presence of virogenic stroma, nucleocapsid assembly, and $\mathrm{OB}$ formation and maturation were also tabulated. GraphPad InStat 3.05 software (GraphPad Software, La Jolla, CA, USA) was used to calculate the $P$ values of cytopathic effects through Kruskal-Wallis non-parametric and Dunn multiple comparison tests.

\section{Results}

Evidence of NeabNPV infection was only observed in the epithelial cells of the midgut (Figures 1, 2, 3, and 4). Fore- and hindguts of infected larvae fixed, embedded in epoxy or paraplast and examined under the compound light microscope, showed no visible signs of NeabNPV infection (data not shown). Patent midgut infections could include most midgut epithelial cells as seen in Figure 2, but there could also be areas of the epithelium where infection was not apparent (Table 1). Healthy midgut epithelial cells were elongated with microvilli at the apical end extending into the ectoperitrophic space of the gut lumen (Figure 5). The nucleus of each cell was centrally located with visible heterochromatin, and invaginations of the nuclear envelope were often visible (Figures 5 and 6). At the basal end, midgut 


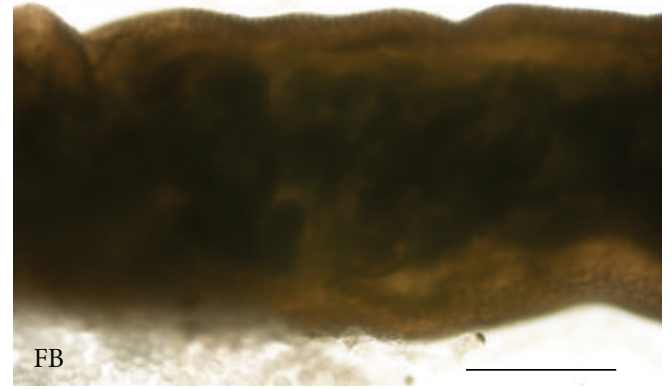

FIGURE 1: Whole mount of a healthy balsam fir sawfly larva midgut. The central region is opaque due to the presence of a food bolus within the gut. Fat body (FB) is present at the lower left. Photomicrograph. Scale bar $=1 \mathrm{~mm}$.

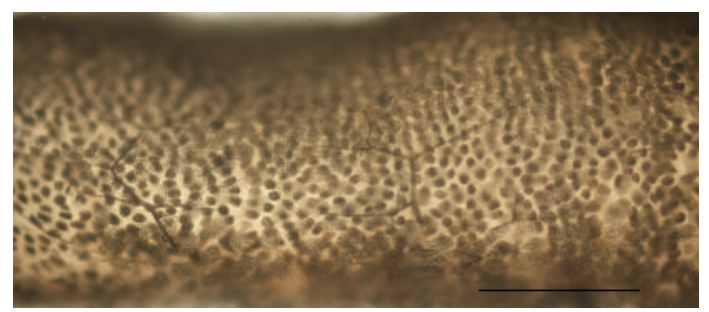

Figure 2: Whole mount of a balsam fir sawfly larva midgut with a patent NeabNPV infection. Nuclei in the epithelial cells throughout the midgut are opaque due to the presence of numerous NeabNPV occlusion bodies. Photomicrograph. Scale bar $=1 \mathrm{~mm}$.

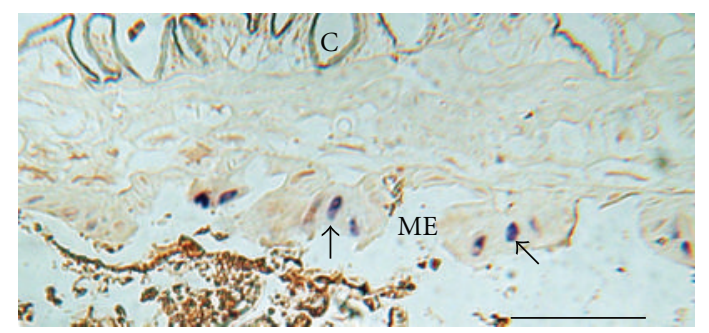

FIGURE 3: In situ hybridization, longitudinal section of an NeabNPV-infected larval midgut at $48-72$ hpi where only a few midgut epithelial cells (ME) have stained positively for NeabNPV DNA (arrows). Cells between the midgut and the cuticle (C) are negative for NeabNPV. Photomicrograph. Scale bar $=3 \mathrm{~mm}$.

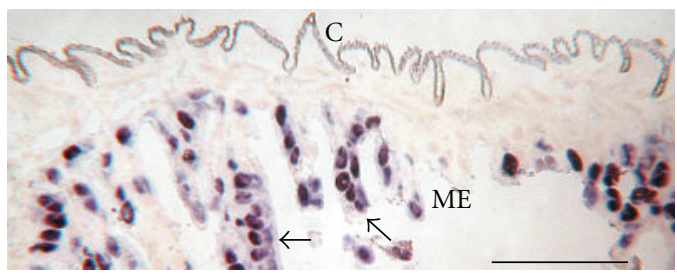

FIGURE 4: In situ hybridization, longitudinal section of a NeabNPVinfected larval midgut at 96-120 hpi where only midgut epithelial cells have stained positively for NeabNPV DNA (arrows). Cells between the midgut and the cuticle $(\mathrm{C})$ are negative for NeabNPV. Photomicrograph. Scale bar $=2 \mathrm{~mm}$.

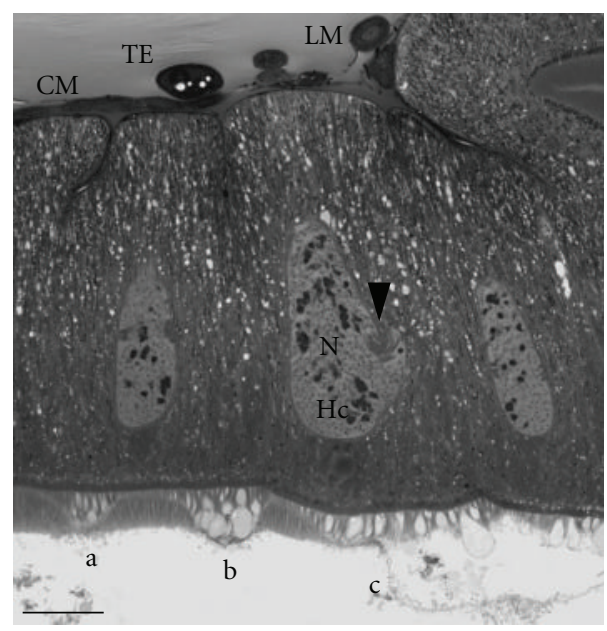

FIGURE 5: Cross-section of a healthy larval midgut. Epithelial cells are elongated and abutted against circular (CM) and longitudinal (LM) muscles; tracheole epithelial cells (TE) are also present. The nucleus $(\mathrm{N})$ is elongated and centrally located in the cell. Heterochromatin ( $\mathrm{Hc}$ ) and invaginations of the nuclear envelope (arrowhead) are evident. Three successive stages of what appears to be a secretory process from these cells $(\mathrm{a}, \mathrm{b}$, and $\mathrm{c})$ are apparent. Epoxy section, photomicrograph. Scale bar $=20 \mu \mathrm{m}$.

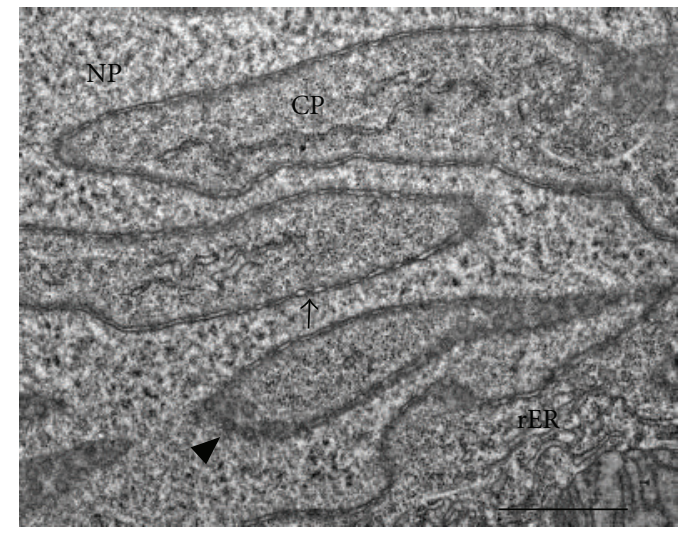

Figure 6: Detail of nuclear envelope invaginations in uninfected midgut epithelial cell. Visible are the nucleoplasm (NP), cytoplasm (CP), nuclear pores in cross (arrowhead) and longitudinal (arrow) sections, and rough endoplasmic reticulum (rER). Electron micrograph. Scale bar $=1 \mu \mathrm{m}$.

epithelial cells abut against a basal lamina and circular and longitudinal muscles (Figures 5, 7, and 8). Invaginations of basal-end plasma membranes of epithelial cells appear to anchor the cells to the basal lamina (Figures 7 and 8). Midgut epithelial cells of balsam fir sawfly larvae outwardly appear to be similar (Figures 5, 9, 10, 11).

Entry of NeabNPV virions into host epithelial cells and nuclei was not observed. Within $5 \mathrm{~h}$ of infection by NeabNPV, there was a proportional decrease in the size of microvillar borders and hypertrophy of nuclei in relation to the area of cells as a whole (Table 2), which coincided with the appearance of virogenic stromata in more than $50 \%$ of midgut epithelial cell nuclei (Table 1). Approximately $50 \%$ or 


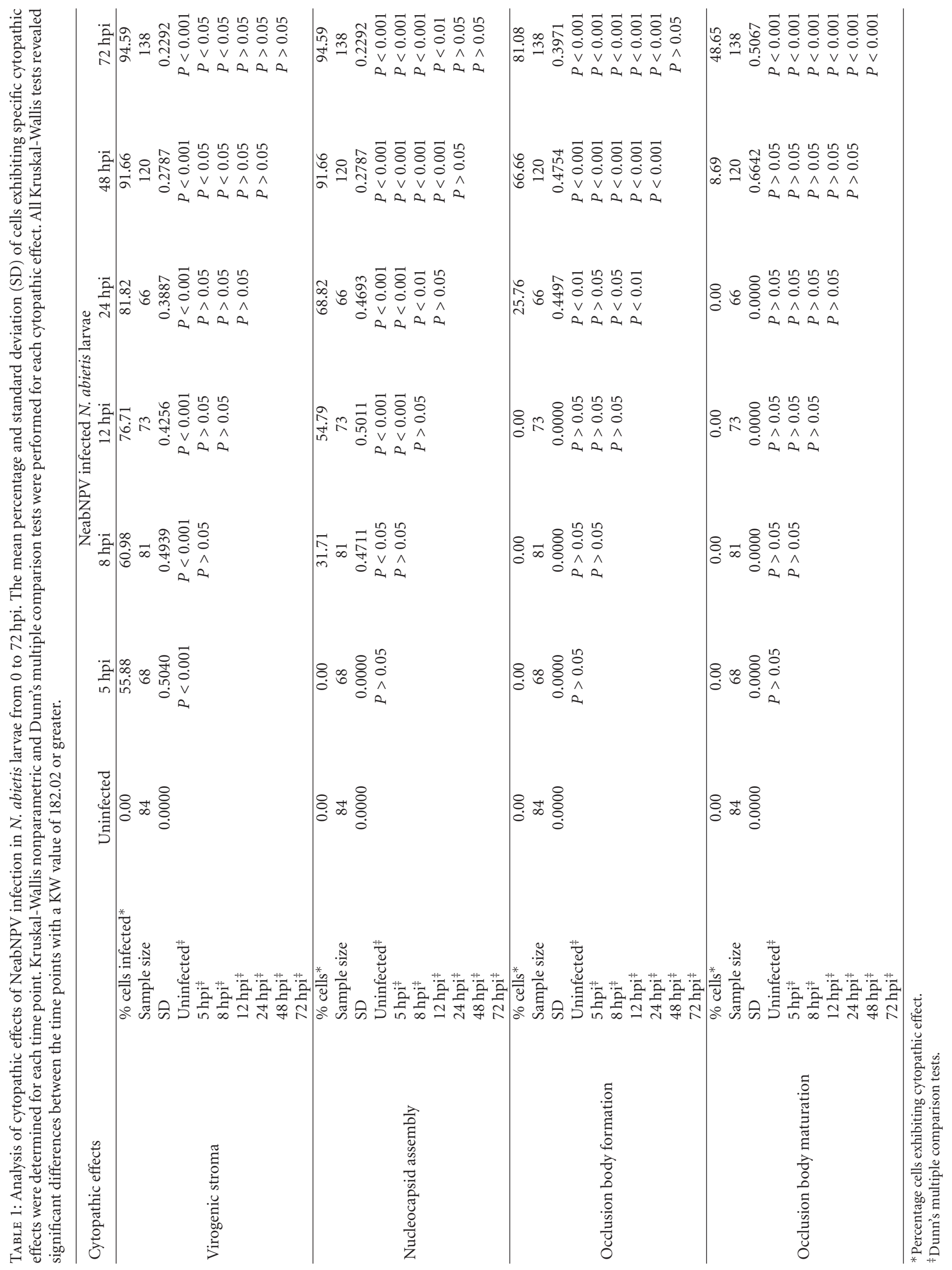




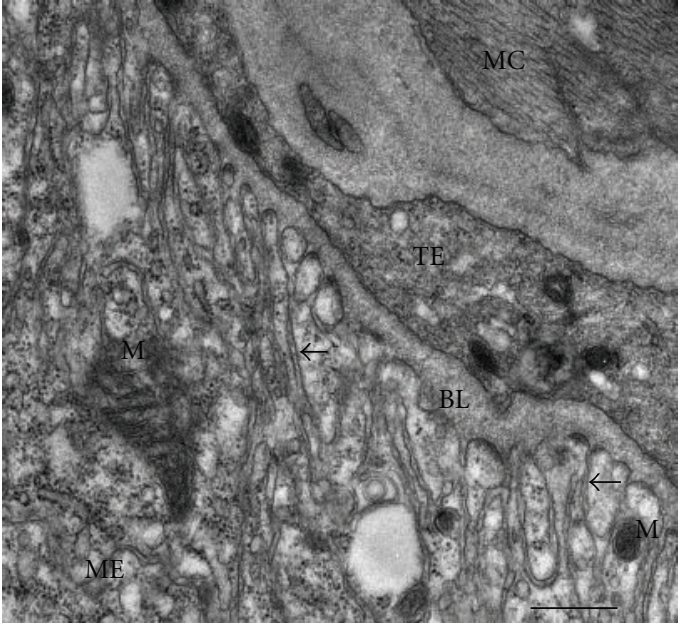

Figure 7: The basal end of an uninfected midgut epithelial cell (ME) abutting against the basal lamina (BL), a tracheole epithelial cell (TE), and a muscle cell (MC). Invaginations of the midgut epithelial cell plasma membrane (arrows) anchor the cell to the basal lamina. Mitochondria (M) were also seen in this region of the midgut cell. Electron micrograph. Scale bar $=0.5 \mu \mathrm{m}$.

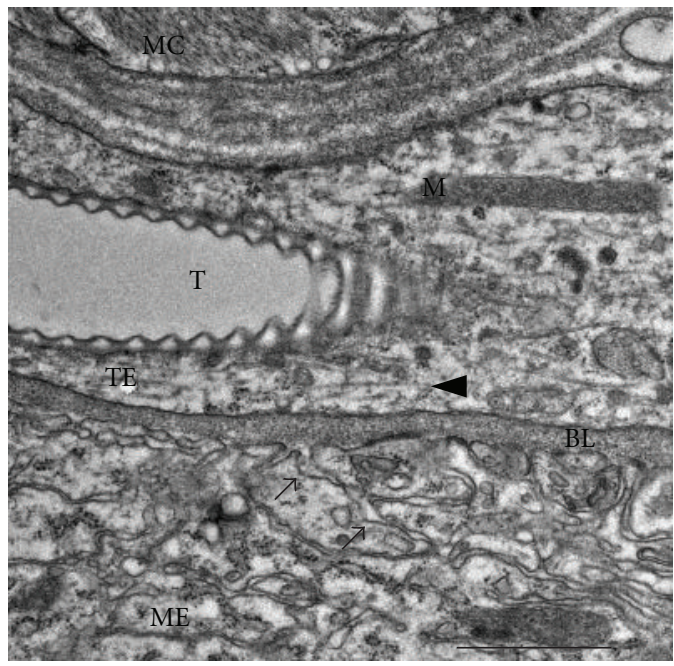

Figure 8: Uninfected midgut (ME), and tracheole epithelial cells (TE) with basal lamina (BL) in between. Invaginations of the midgut epithelial cell plasma membrane (arrows) anchor the cell to the basal lamina. A tracheole ( $\mathrm{T})$, mitochondrion (M), and microtubules (arrowhead) can be seen in the tracheole epithelial cell. A muscle cell (MC) lies adjacent to the tracheole epithelial cell. Electron micrograph. Scale bar $=1 \mu \mathrm{m}$.

more of midgut cells examined by electron microscopy had nucleocapsid formation by $12 \mathrm{hpi}$, OB formation by $48 \mathrm{hpi}$, and OB maturation by $72 \mathrm{hpi}$ (Table 1). Dissolution of areas of the basal lamina was apparent by $48 \mathrm{hpi}$ (Figures 12 and 13). Bacteria within the cytoplasm of affected cells were evident by 48 hpi (Figures 12 and 13) and quite prevalent by 72 hpi (Figure 16). Formation of cytoplasmic vesicles containing electron-opaque material was first observed at $48 \mathrm{hpi}$,

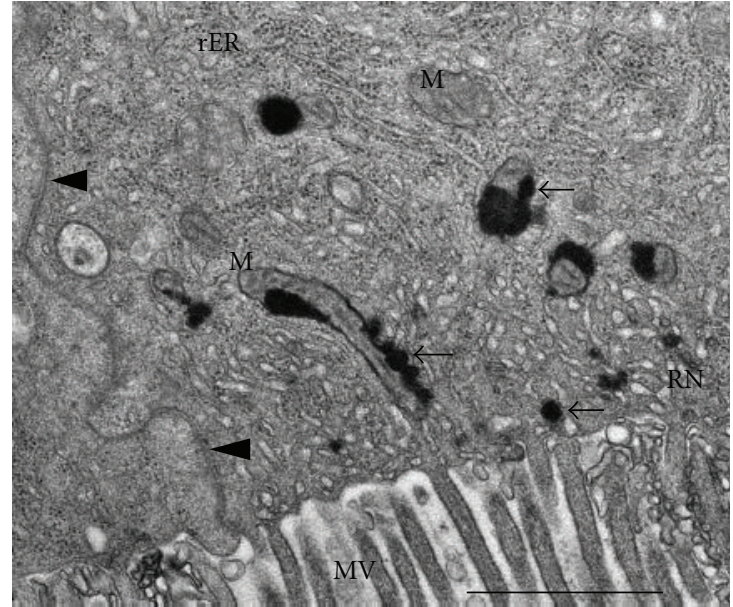

Figure 9: Apical end of an uninfected midgut epithelial cell. The cytoplasm contains mitochondria (M), rough endoplasmic reticulum (rER), and, near where microvilli (MV) extend out into the midgut lumen, a reticulate network (RN). Electron opaque material (arrows) was observed around mitochondria and the reticulate network. The zonula continua separating two epithelial cells can be seen on the left (arrowheads). Electron micrograph. Scale bar $=$ $1 \mu \mathrm{m}$.

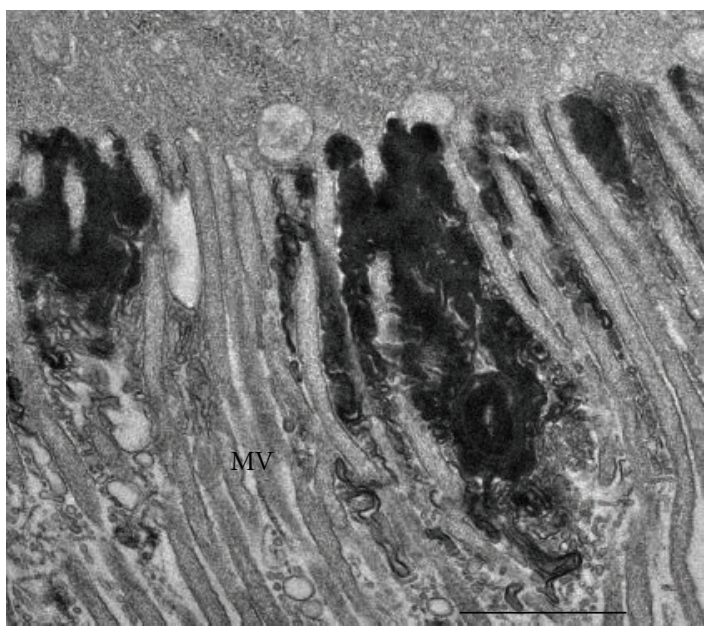

FIGURE 10: Electron opaque material, similar in appearance to that seen in Figure 9, in the gut lumen, adjacent to an uninfected midgut epithelial cell, and in between the microvilli (MV). Electron micrograph. Scale bar $=1 \mu \mathrm{m}$.

and massed thread-like structures at $72 \mathrm{hpi}$ (Figures 14, 15, and 16). General features of nucleocapsid and $\mathrm{OB}$ formation are shown in Figures 17-24. Virogenic stromata were only evident in the nuclei of mature midgut epithelial cells but not in the nuclei of regenerative cells (Figure 17). Viral capsids and nucleocapsids were elongate, and were observed together in clusters within virogenic stromata (Figures 18 and 19). Nucleocapsids were singly enveloped prior to occlusion into OBs (Figures 18, 20, and 21). Circular bodies of unknown composition were also observed within virogenic stromata (Figure 20). By 96 hpi, mature OBs were present in most, but 


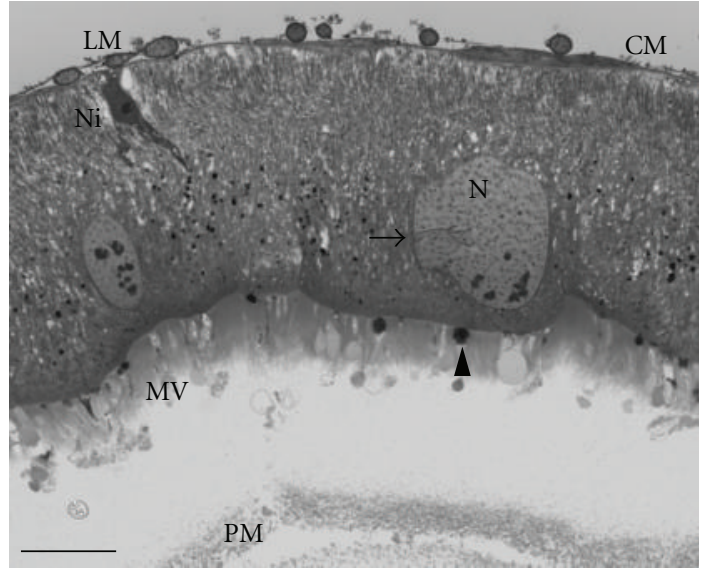

Figure 11: Cross-section of midgut epithelial cells at 48 hpi with NeabNPV. The basal ends of the epithelial cells abut against circular (CM) and longitudinal (LM) muscles. A nidus of regenerative cells $(\mathrm{Ni})$ lies between two epithelial cells. The nucleus $(\mathrm{N})$ appears enlarged, and invaginations (arrow) of the nuclear envelope are present. Dark-staining bodies (arrowhead) (perhaps the same as those observed in Figure 10) are present in the epithelial microvilli $(\mathrm{MV})$. The peritrophic membrane (PM) is present in the gut lumen. Epoxy section, photomicrograph. Scale bar $=20 \mu \mathrm{m}$.

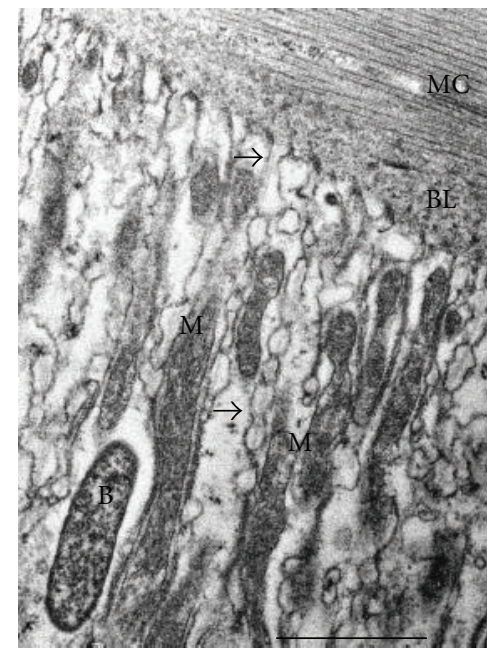

FIgUre 12: Basal end of a midgut epithelial cell at 48 hpi. A layer of basal lamina (BL) lies between the midgut cell and a muscle cell (MC). Mitochondria (M) and a bacterium (B) can be seen in the cytoplasm of the midgut cell in between the invaginations of the plasma membrane (arrows). These plasma membrane invaginations appear irregular compared with those in Figures 7 and 8. Electron micrograph. Scale bar $=1 \mu \mathrm{m}$.

not all, midgut epithelial cell nuclei (Figures 22, 23, and 24). Gaps between the basal ends of epithelial cells and midgut musculature were also apparent at this time (Figure 22). By 120 hpi, NeabNPV-infected cells had detached from the midgut epithelium, leaving gaps between the remaining attached cells, and were free within the midgut lumen (Figures 25 and 26). Bacteria were present both in the midgut lumen and in the host hemocoel (Figures 25 and 26). Cell

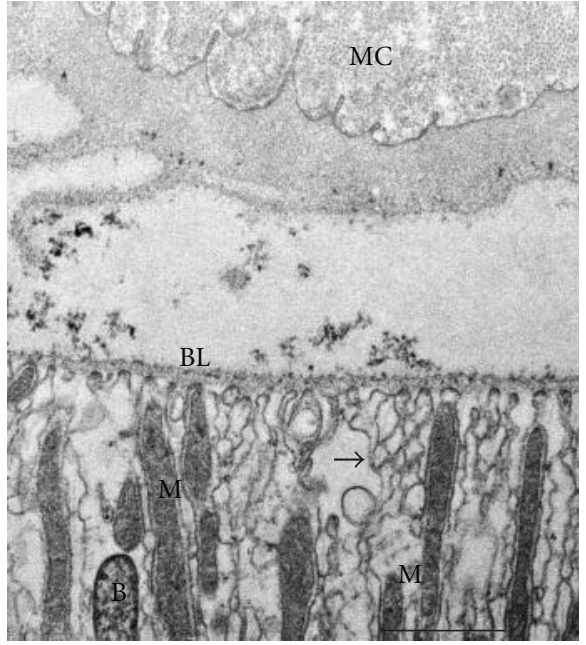

FIgURE 13: Basal end of a midgut epithelial cell at 48 hpi similar to that seen in Figure 12. There is a gap between the muscle (MC) at the top and the basal lamina (BL), which consists only of a thin layer along the outer edge of the midgut cell, and no laminar material can be seen within the midgut cell plasma membrane invaginations (arrows), which appear irregular compared with those in Figures 7 and 8 . A bacterium (B) and mitochondria (M) are present in the midgut cell cytoplasm. Electron micrograph. Scale bar $=1 \mu \mathrm{m}$.

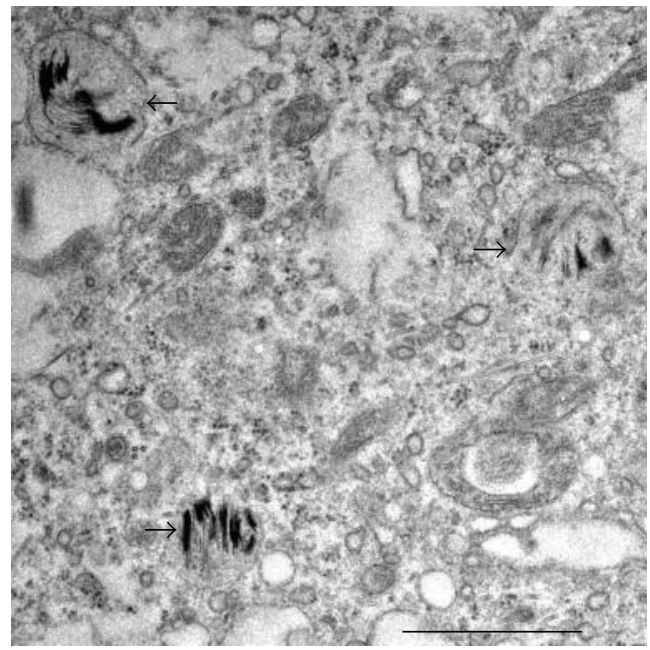

FIGURE 14: Early stage in the formation of vesicles (arrows) accumulating electron opaque material in the cytoplasm of a midgut epithelial cell at $48 \mathrm{hpi}$. Electron micrograph. Scale bar $=1 \mu \mathrm{m}$.

lysis was apparent at $120 \mathrm{hpi}$ (Figures 26 and 27), and free OBs were also present in the midgut lumen at late stages of infection (Figures 28 and 29). Midgut epithelial cell nuclei full of NeabNPV OBs were also observed in active adult female balsam fir sawflies (Figure 30).

\section{Discussion}

Within the Baculoviridae, the genera Gammabaculovirus and Deltabaculovirus are thought to be the most ancient because 
TABle 2: Cytopathic effects due to NeabNPV infection resulting in reduction in the microvillar border and nuclear hypertrophy based on mean values of the proportional surface area of each compared with the area of the affected cells from 0 to 72 hpi. Proportional mean values and standard deviations (SD) were determined for each time point. Kruskal-Wallis nonparametric and Dunn's multiple comparison tests were performed for each cytopathic effect to obtain a measure of the statistical significance of each trait over the course of infection. All Kruskal-Wallis tests revealed significant differences between the time points with a KW value of 52.74 or greater.

\begin{tabular}{|c|c|c|c|c|c|c|c|c|c|c|}
\hline \multirow{2}{*}{$\begin{array}{l}\text { Cytopathic } \\
\text { effects }\end{array}$} & & \multicolumn{9}{|c|}{ NeabNPV infected N. abietis larvae } \\
\hline & & Uninfected & 1 hpi & 2 hpi & 5 hpi & 8 hpi & 12 hpi & 24 hpi & 48 hpi & 72 hpi \\
\hline \multirow{12}{*}{$\begin{array}{l}\text { Microvillar } \\
\text { reduction }\end{array}$} & Mean* & 25.45 & 25.49 & 25.27 & 14.94 & 15.83 & 18.26 & 18.15 & 10.20 & 15.14 \\
\hline & Sample size & 84 & 79 & 65 & 68 & 81 & 73 & 66 & 120 & 138 \\
\hline & $\mathrm{SD}$ & 0.0717 & 0.0728 & 0.0763 & 0.0363 & 0.0407 & 0.0660 & 0.0532 & 0.0562 & 0.0790 \\
\hline & Uninfected $^{\ddagger}$ & & $P>0.05$ & $P>0.05$ & $P<0.001$ & $P<0.001$ & $P<0.001$ & $P<0.001$ & $P<0.001$ & $P<0.001$ \\
\hline & $1 \mathrm{hpi}^{\ddagger}$ & & & $P>0.05$ & $P<0.001$ & $P<0.001$ & $P<0.001$ & $P<0.001$ & $P<0.001$ & $P<0.001$ \\
\hline & $2 \mathrm{hpi}^{\ddagger}$ & & & & $P<0.001$ & $P<0.001$ & $P<0.001$ & $P<0.001$ & $P<0.001$ & $P<0.001$ \\
\hline & $5 \mathrm{hpi}^{\ddagger}$ & & & & & $P>0.05$ & $P>0.05$ & $P>0.05$ & $P<0.01$ & $P<0.05$ \\
\hline & $8 \mathrm{hpi}^{\ddagger}$ & & & & & & $P>0.05$ & $P>0.05$ & $P<0.01$ & $P<0.05$ \\
\hline & $12 \mathrm{hpi}^{\ddagger}$ & & & & & & & $P>0.05$ & $P<0.01$ & $P>0.05$ \\
\hline & $24 \mathrm{hpi}^{\ddagger}$ & & & & & & & & $P<0.01$ & $P>0.05$ \\
\hline & $48 \mathrm{hpi}^{\ddagger}$ & & & & & & & & & $P<0.01$ \\
\hline & $72 \mathrm{hpi}^{\ddagger}$ & & & & & & & & & \\
\hline \multirow{12}{*}{$\begin{array}{l}\text { Nuclear } \\
\text { hypertrophy }\end{array}$} & Mean $^{\dagger}$ & 29.35 & 28.92 & 29.54 & 42.35 & 42.35 & 38.15 & 37.36 & 43.87 & 48.70 \\
\hline & Sample size & 84 & 79 & 65 & 68 & 81 & 73 & 66 & 120 & 138 \\
\hline & $\mathrm{SD}$ & 0.1160 & 0.1073 & 0.1127 & 0.1572 & 0.1572 & 0.1535 & 0.1127 & 0.6447 & 0.0871 \\
\hline & Uninfected $^{\ddagger}$ & & $P>0.05$ & $P>0.05$ & $P<0.001$ & $P<0.001$ & $P<0.001$ & $P<0.001$ & $P<0.001$ & $P<0.001$ \\
\hline & $1 \mathrm{hpi}^{\ddagger}$ & & & $P>0.05$ & $P<0.001$ & $P<0.001$ & $P<0.001$ & $P<0.001$ & $P<0.001$ & $P<0.001$ \\
\hline & $2 \mathrm{hpi}^{\ddagger}$ & & & & $P<0.001$ & $P<0.001$ & $P<0.001$ & $P<0.001$ & $P<0.001$ & $P<0.001$ \\
\hline & $5 \mathrm{hpi}^{\ddagger}$ & & & & & $P>0.05$ & $P>0.05$ & $P>0.05$ & $P<0.05$ & $P>0.05$ \\
\hline & $8 \mathrm{hpi}^{\ddagger}$ & & & & & & $P>0.05$ & $P>0.05$ & $P<0.05$ & $P>0.05$ \\
\hline & $12 \mathrm{hpi}^{\ddagger}$ & & & & & & & $P>0.05$ & $P>0.05$ & $P>0.05$ \\
\hline & $24 \mathrm{hpi}^{\ddagger}$ & & & & & & & & $P>0.05$ & $P>0.05$ \\
\hline & $48 \mathrm{hpi}^{\ddagger}$ & & & & & & & & & $P>0.05$ \\
\hline & $72 \mathrm{hpi}^{\ddagger}$ & & & & & & & & & \\
\hline
\end{tabular}

* Proportional surface area of the microvillar border compared with the surface area of the entire cell (\%).

${ }^{\dagger}$ Proportional surface area of the nucleus compared with the surface area of the entire cell (\%).

‡Dunn's multiple comparison tests.

of their smaller genomes, limited tissue tropism [3, 28, 29], and more ancient lineage of their hosts $[10,11,30]$ compared with Alphabaculovirus and Betabaculovirus. Although still distantly, gammabaculoviruses are thought to be more closely related than deltabaculoviruses to alphabaculoviruses and betabaculoviruses [3]. However, gammabaculoviruses appear to lack an envelope fusion protein homolog [22, 28,31 ] and, as a consequence, lack a budded virus (BV) phenotype common to the other three genera. Group I alphabaculoviruses, such as that of Autographa californica (AcMNPV), encode GP-64 [32] whereas group II NPVs, for example, Lymantria dispar LdMNPV, encode F-protein [33]. Sequence data have identified F-protein homologs in betabaculoviruses $[34,35]$ and the Culex nigripalpus Deltabaculovirus (CuniNPV) [36], indicating that F-protein may be more ancestral in baculoviruses [37]. Further evidence of the restriction of gammabaculoviruses and deltabaculoviruses to gut tissues is the absence of viral fibroblast growth factor (vfgf) homologs [1] that aid the establishment of alphabaculovirus systemic infections [38-40]. Viral FGFs mimic host FGFs that trigger fibroblast growth factor receptor-mediated migration of tracheal cells to the midgut epithelium. Here, the tracheal cells release enzymes that degrade the basal lamina, which otherwise forms an impenetrable barrier, thus allowing BV to exit from the midgut epithelium and infect tracheal and other cells in the host hemocoel [40].

To date, neither Deltabaculovirus [36] nor Gammabaculovirus genomes $[22,28,31]$ have been found to encode enhancin genes. Enhancins are metalloproteases that degrade mucins in insect gut peritrophic membranes, thereby allowing baculovirus occlusion-derived virus (ODV) to cross this physical barrier to the midgut epithelium [41, 42]. It is unclear, therefore, how deltabaculoviruses and gammabaculoviruses achieve this feat. Although NeabNPV virion entry into midgut epithelial cells and nuclei was not observed, these two processes likely proceed in a similar manner to 


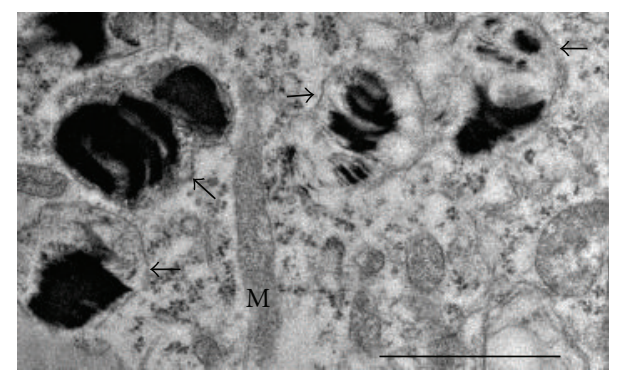

FIGURE 15: On either side of a mitochondrion (M) are vesicles at later stages of formation than those observed in Figure 14 but still in a midgut epithelial cell at $48 \mathrm{hpi}$. Vesicle membranes are indicated by the arrows. Electron micrograph. Scale bar $=1 \mu \mathrm{m}$.

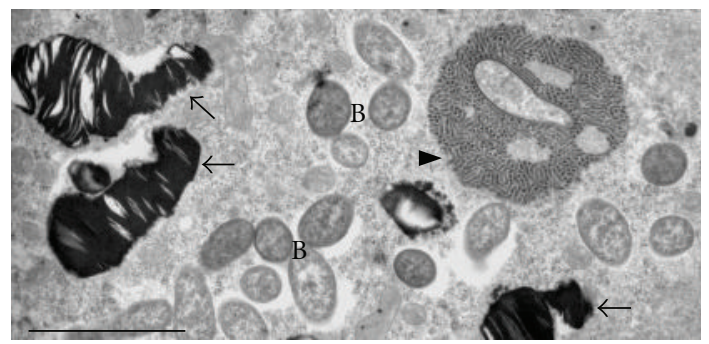

Figure 16: Midgut epithelial cell at 72 hpi. Present in the cytoplasm are vesicles containing an electron opaque material (arrows) and bacteria (B). Structures (arrowhead) appearing to consist of lengths of a thread-like material were first observed at 72 hpi. Electron micrograph. Scale bar $=1 \mu \mathrm{m}$.

other baculoviruses, as gammabaculoviruses possess the core genes, found in all baculoviruses, that are associated with oral infectivity, namely, pif-0 (p74), pif-1, pif-2, pif3 , pif-4 (19k/odv-e28) and pif-5 (odv-e56) [35]. The initial infection process of NeabNPV host-cell entry appears to occur between 0.5 and 4 hpi followed by a rapid rate of increase in NeabNPV DNA copy number between 4 and $24 \mathrm{hpi}$ and a slower rate of increase between 24 and $72 \mathrm{hpi}$ [23]. In this same study, Duffy et al. [23] used RT-PCR to examine the sequence of expression of selected NeabNPV genes in N. abietis larvae to $72 \mathrm{hpi}$. Transcription of all NeabNPV genes examined was detected through to $72 \mathrm{hpi}$, with first detection of early expressed genes lef- 8 at $1 \mathrm{hpi}$, lef-1, lef-2, and dnapol at $2 \mathrm{hpi}$, and lef-9 at $6 \mathrm{hpi}$ along with late-expressed genes $g p 41$ and $p 74$. Very-late-expressed genes $v l f-1$ and polh were first detected at 12 and $24 \mathrm{hpi}$, respectively. These results suggest that the temporal sequence of NeabNPV gene expression is similar to patterns reported for lepidopteran alphabaculoviruses [23].

Insect midgut epithelial cells are generally short lived and are rapidly replaced by regenerative cells at the basal end and in between the epithelial cells [43]. A defense against microbial infection can be the early onset of programmed cell death or apoptosis of the infected cell. This can present a challenge in the establishment of midgut infections by baculoviruses. Baculovirus genomes (except CuniNPV [36]) encode two types of gene products that suppress apoptosis, P-35-like and inhibitors of apoptosis (IAP) (review

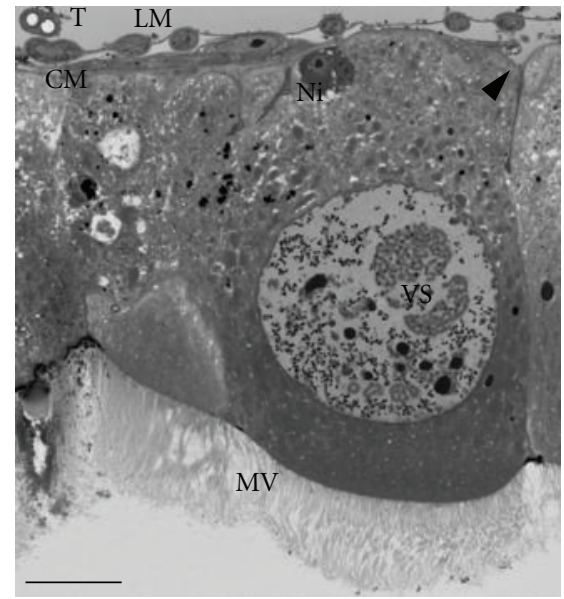

FIGURE 17: Cross-section of midgut epithelium at $72 \mathrm{hpi}$. Midgut epithelial cells abut circular (CM) and longitudinal (LM) muscle, and regenerative cells (Ni) are present. Virogenic stroma (VS) can be seen within the hypertrophied nucleus. Secretory activity appears to have been reduced or has ceased as no secretions, such as those seen in Figures 5, 10, and 11, were evident in the microvilli (MV) from this time point onward. Epoxy section, photomicrograph. Scale bar $=20 \mu \mathrm{m}$.

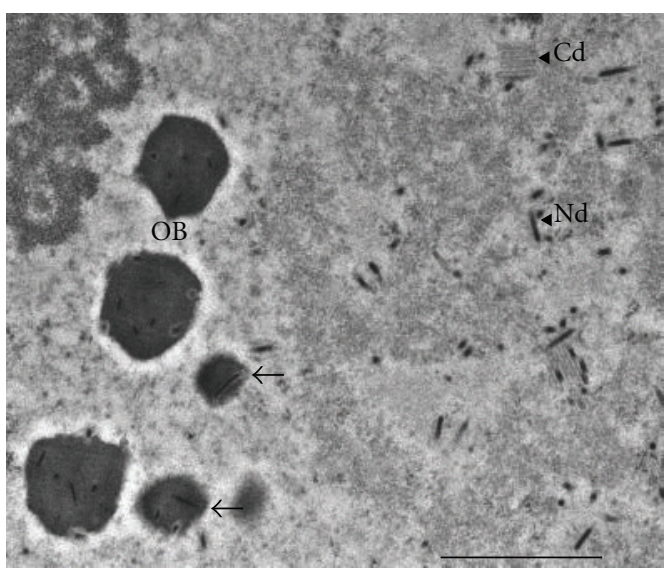

FIGURE 18: Virogenic stroma in the nucleus of a midgut epithelial cell at 72 hpi. Viral capsids (Cd) and nucleocapsids (Nd) can be seen nucleocapsids being occluded (arrows) into forming occlusion bodies (OBs). Electron micrograph. Scale bar $=1 \mu \mathrm{m}$.

[37]). The genomes of NeabNPV [22], and the gammabaculoviruses of N. lecontei (NeleNPV) [28] and N. sertifer (NeseNPV) [31] contain iap genes that may have transferred from insect hosts [44]. NeabNPV IAP shares $75 \%$ amino acid identity with NeleNPV IAP but only $24 \%$ identity with NeseNPV IAP [22]. How IAP proteins interfere with apoptosis is not well understood, and gammabaculovirus IAPs are not among the few baculovirus IAPs that have been functionally characterized and confirmed to be inhibitors of apoptosis (review [37]). However, nuclear condensation and fragmentation are characteristic morphological features of apoptosis (review [45]), and nuclear fragmentation, at least, was not observed to occur in NeabNPV-infected cells. In 


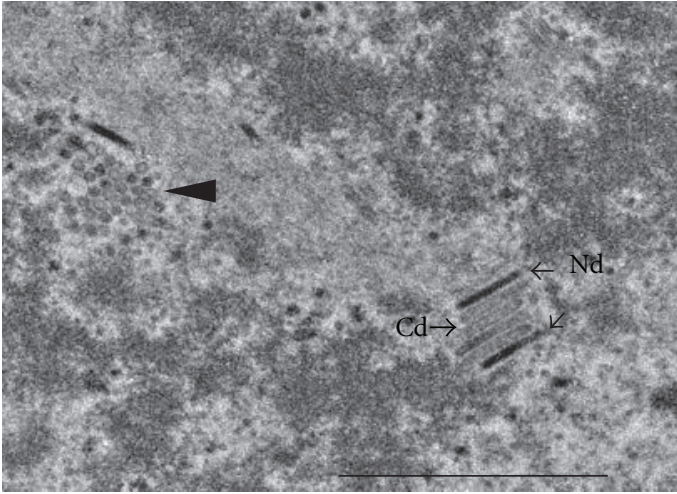

FIGURE 19: Virogenic stroma in the nucleus of a midgut epithelial cell at 96 hpi. Viral capsids (Cd) and nucleocapsids (Nd) can be seen in longitudinal section and in cross-section (arrowhead). Electron micrograph. Scale bar $=1 \mu \mathrm{m}$.

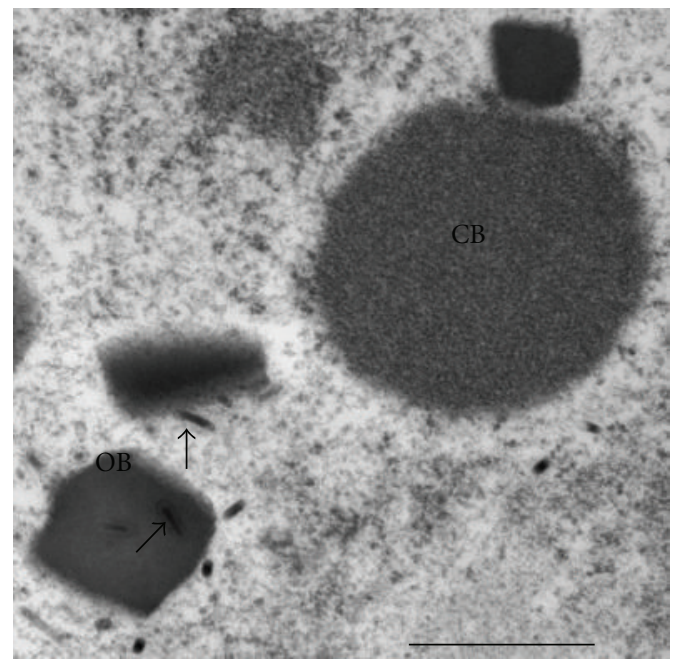

FIgURE 20: Virogenic stroma in the nucleus of a midgut epithelial cell at 96 hpi showing a circular body (CB) and nucleocapsid (arrows) occlusion into occlusion bodies (OBs). Electron micrograph. Scale bar $=0.5 \mu \mathrm{m}$.

alphabaculovirus-infected cells, heterochromatin becomes localized at the margins of the nucleus as the virogenic stoma develops [46, 47]. Condensed heterochromatin was observed in apparently healthy cells (Figure 5) and in NeabNPV-infected cells (Figure 23) but does not appear to be concentrated at the margins of the nucleus in either case. Gammabaculoviruses NeabNPV, NeleNPV, and NeseNPV all have homologs to regulator of chromosome condensation proteins (RCC1) that regulate chromosome condensation by binding to DNA or chromatin-associated proteins (review [48]). However, we do not know whether RRC1 was a factor in heterochromatin condensation in the case of NeabNPV infection.

With $\mathrm{OB}$ formation initiation in $81 \%$ and maturation in $49 \%$ of epithelial cells in NeabNPV-infected midgut within $72 \mathrm{hpi}$ (Table 1) and cell sloughing by $120 \mathrm{hpi}$ (Figure 26), the timing of $\mathrm{OB}$ development and release in NeabNPV

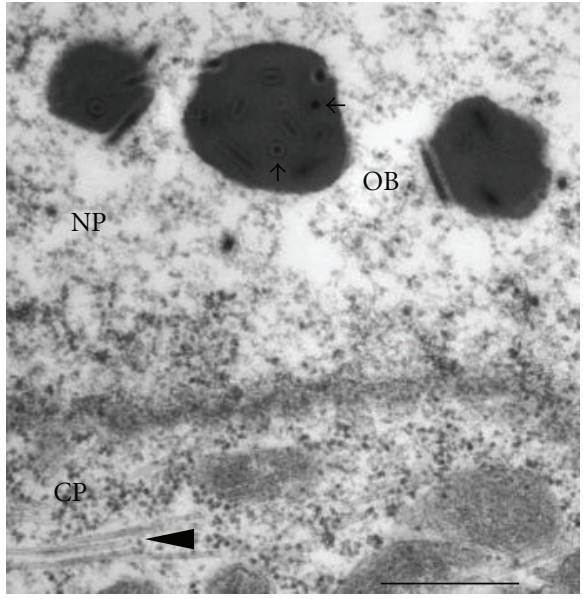

Figure 21: Occlusion of nucleocapsids into occlusion bodies (OBs) in the nucleoplasm of a midgut epithelial cell at $96 \mathrm{hpi}$. Two nucleocapsids (arrows) have been cut in clear cross-section. Microtubules (arrowheads) are present in the cell cytoplasm (CP). Electron micrograph. Scale bar $=0.5 \mu \mathrm{m}$.

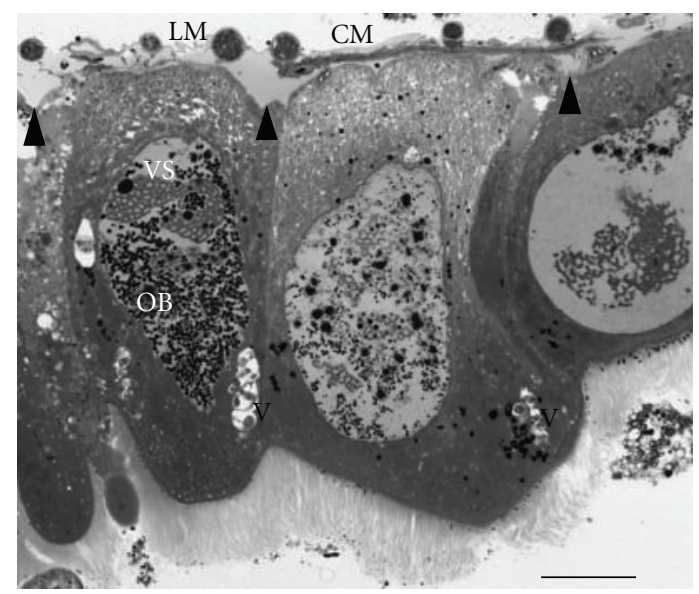

Figure 22: Cross-section of midgut epithelial cells at 96 hpi. Clear gaps (arrowheads) separate the basal ends of the epithelial cells from adjacent circular (CM) and longitudinal (LM) muscles. Virogenic stroma (VS) and occlusion bodies (OBs) occupy much of the enlarged nucleus on the left. Note that the level of NeabNPV development does not appear to be the same in the three visible nuclei. Large vacuoles (V) can be seen in the cytoplasm of two of the cells. Epoxy section, photomicrograph. Scale bar $=20 \mu \mathrm{m}$.

appear to be similar to midgut-limited Harrisina brillians Betabaculovirus (HabrGV) [49]. Unfortunately, the genome of HabrGV has not been sequenced, and it is not clear whether or not there is a BV phenotype [25], although there appears to be secondary infection of regenerating cells after the sloughing of earlier-infected epithelial cells [49]. To the best of our knowledge, the loss of integrity of the midgut epithelium basal lamina, as we have observed with NeabNPV infection, has not been documented in either HabrGV [49] or CuniNPV [29] and, generally, is not a feature of either alphabaculovirus or betabaculovirus infections (review [25]). Otherwise, NeabNPV nucleocapsid assembly, 


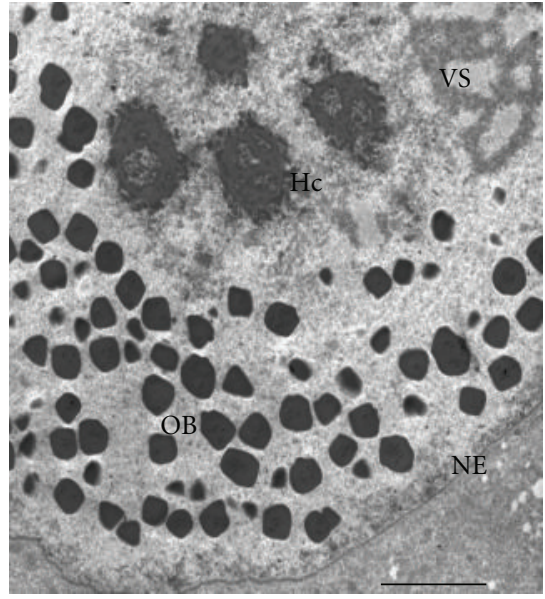

Figure 23: Nucleus of a midgut epithelial cell at 96 hpi. Heterochromatin (Hc), virogenic stroma (VS), and NeabNPV occlusion bodies (OB) lie within the nuclear envelope (NE). Electron micrograph. Scale bar $=2 \mu \mathrm{m}$.

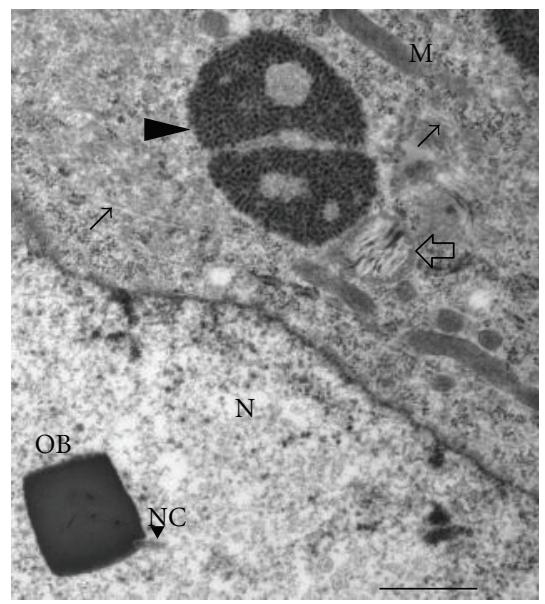

Figure 24: Midgut epithelial cell at 96 hpi. A thread-like body (arrowhead), similar to that seen in Figure 16, lies within the cell cytoplasm along with mitochondria (M), microtubules (arrows) and a developing vesicle containing electron-opaque material (open arrow) similar to those in Figures 14-16. A nucleocapsid (Nc) can be seen being occluded at the lower right corner of an occlusion body $(\mathrm{OB})$ within the nucleus $(\mathrm{N})$. Electron micrograph. Scale bar $=$ $0.5 \mu \mathrm{m}$.

envelopment and occlusion into OBs appears to be very similar to ODV assembly and occlusion in alphabaculoviruses (review [46]). One difference, however, is the apparent absence of $p$-10-rich fibrillar bodies that are present in the nuclei of late-stage, alphabaculovirus-infected cells and are often associated with OB calyx formation (review [46]). Gammabaculovirus genomes sequenced to date do not have a $p$-10 gene homolog $[22,28,31]$ but $\mathrm{P}-10$ is not required for calyx formation $[50,51]$.

The epithelial cells of healthy Neodiprion larval midguts [52], including N. abietis [26], appear to be fairly uniform. This is not to say that cells in different parts of the midgut

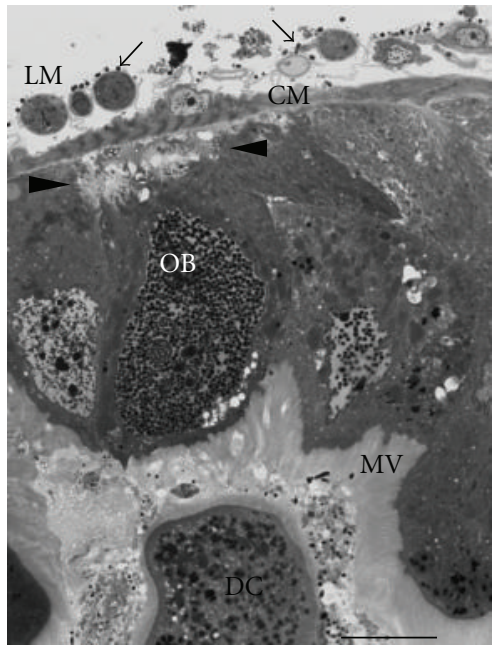

FIgure 25: Cross-section of midgut epithelium at $120 \mathrm{hpi}$. The enlarged nucleus of the cell, to the left of center, is full of occlusion bodies (OB). The basal end of this cell lies proximal to circular muscle but the cytoplasm in this region of the cell appears vacuolated (between arrowheads). Bacteria (arrows) are present in the hemocoel adjacent to longitudinal muscles (LM). An epithelial cell has detached (DC) from the midgut epithelium and is free within the gut lumen near the microvilli (MV) of the surrounding, still attached, midgut cells. Epoxy section, photomicrograph. Scale bar $=20 \mu \mathrm{m}$.

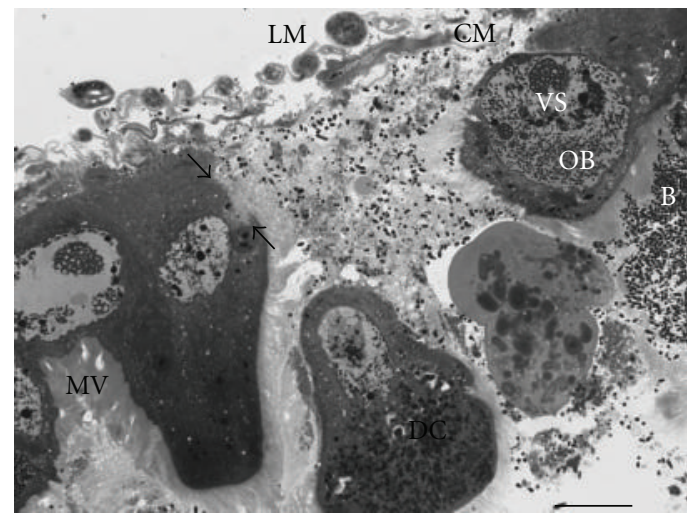

FIgure 26: Cross-section of midgut epithelium at 120 hpi. One cell has detached (DC) from the midgut epithelium. This process results in gaps in the epithelium layer where there are no cells lying adjacent to circular (CM) and longitudinal (LM) muscles. Masses of bacteria (B) lie, in the gut lumen, adjacent to an epithelial cell with an enlarged nucleus containing virogenic stroma (VS) and occlusion bodies (OBs). There appears to be a disruption in the cytoplasm (between arrows) of the epithelial cell to the left of the gap in the epithelium. Microvilli (MV) are evident in this and the adjoining epithelial cell. Epoxy section, photomicrograph. Scale bar $=20 \mu \mathrm{m}$.

may not serve different functions, but most, if not all, are probably involved in several functions including enzyme secretion, nutrient absorption, assimilation, and transport [53]. As NeabNPV-infected cells transition from host-cell functions to viral replication, these host-cell processes may become aberrant before ceasing altogether. This might 


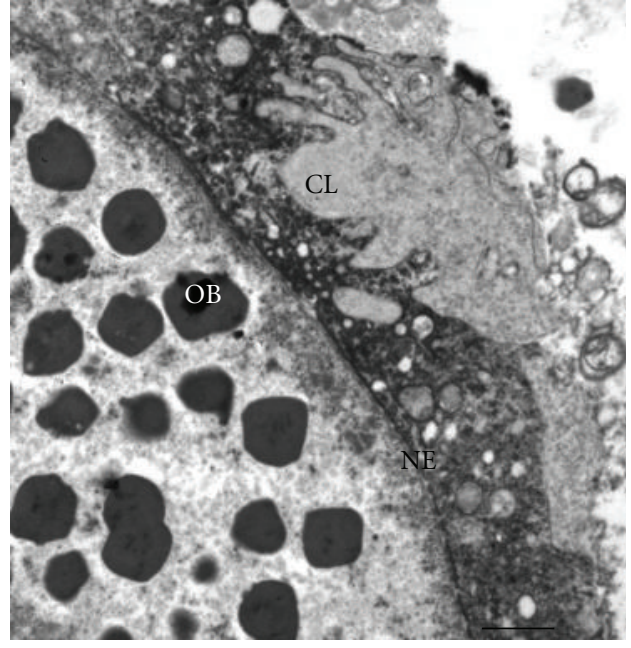

Figure 27: Area of cell cytoplasmic lysis (CL) adjacent to the nuclear envelope (NE) of a midgut epithelial cell at $120 \mathrm{hpi}$. Occlusion bodies (OBs) are present within the nucleus. Electron micrograph. Scale bar $=1 \mu \mathrm{m}$.

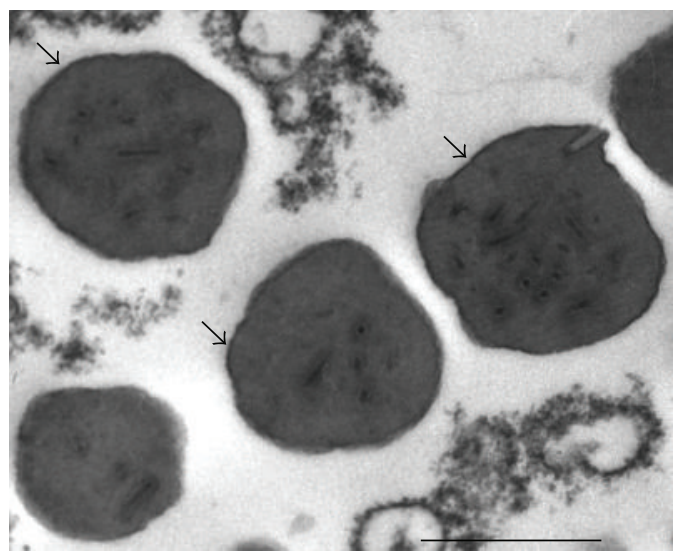

FIgURE 28: Occlusion bodies free in the midgut lumen at $120 \mathrm{hpi}$. Note the calyx-like covering (arrows) surrounding each occlusion body. Electron micrograph. Scale bar $=1 \mu \mathrm{m}$.

explain why we observed structures in the cytoplasm of NeabNPV-infected cells (e.g., vesicles containing electronopaque material and thread-like structures; Figure 16) not seen previously [26] or here in healthy balsam fir sawfly larval midgut cells (Figures 5-10).

As is the case with HabrGV gut infections [49], NeabNPV infections can be carried over into adults. In aerial applications of gammabaculovirus biological control agents, effective application rates can be as low as $1 \times 10^{9} \mathrm{OBs} / \mathrm{ha}$ whereas, when effective, alphabaculoviruses are applied at $10^{10}$ to $10^{12} \mathrm{OBs} / \mathrm{ha}[20,54]$. This is likely the case because of rapid horizontal transmission of NeabNPV due to the sloughing off of infected gut cells from live, infected sawfly larvae, the resultant contamination of foliage, and the gregarious nature of diprionid sawflies $[18,20,55,56]$. When infected with low levels of inoculum and/or as late instars, individual sawflies can survive to adulthood where

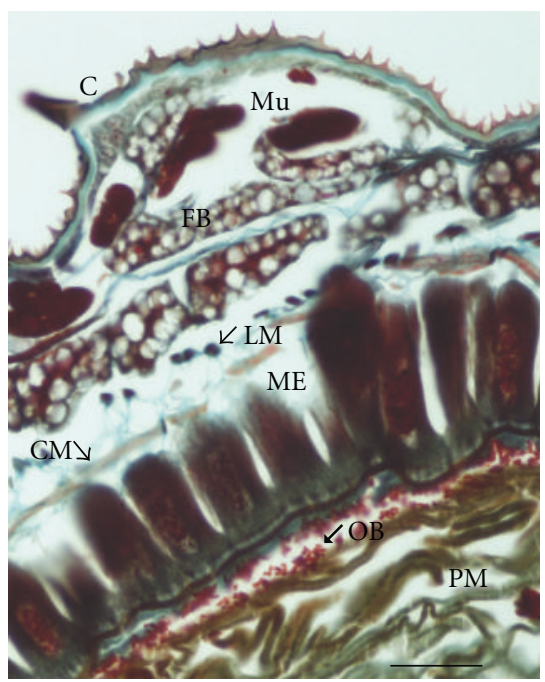

Figure 29: Cross-section of a balsam fir larva at a late stage of NeabNPV infection. Viral occlusion bodies (OBs) lie in the ectoperitrophic space between the peritrophic membrane (PM) and the midgut epithelium (ME). Tissues visible in the hemocoel include circular (CM) and longitudinal (LM) muscle, fat body (FB), and larger muscle masses $(\mathrm{Mu})$ beneath the cuticle $(\mathrm{C})$. Paraplast section, photomicrograph. Scale bar $=50 \mu \mathrm{m}$.

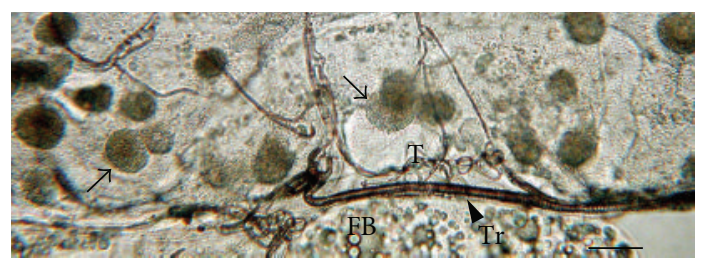

FIgURE 30: Whole mount of a midgut from a live, adult, female balsam fir sawfly. Masses of NeabNPV occlusion bodies can be seen within the nuclei (arrows) of midgut epithelial cells. Also visible are fat body $(\mathrm{FB})$ and trachea $(\mathrm{Tr})$ from which tracheoles $(\mathrm{T})$ branch. Photomicrograph. Scale bar $=50 \mu \mathrm{m}$.

OBs are present in the midgut epithelium (Figure 30). Although there is no evidence for transovarial transmission of gammabaculoviruses, it seems quite possible that adult female sawflies could contaminate oviposition sites with viral OBs passed from their guts. Gammabaculovirus OBs are known to survive on foliage in forest environments for at least 2 years [57], yielding high levels of larval mortality as a result [55].

This paper on the cytology of NeabNPV infection in balsam fir sawflies is quite possibly the first detailed account of gammabaculovirus pathology since the earlier work of Bird and Whalen in 1954 [24]. Despite being effective biological control agents of diprionid sawfly populations [14, 21], interest, such as that seen for alphabaculoviruses, has been lacking largely because of the absence of in vitro culture systems for gammabaculoviruses and reliance on fluctuating field populations of sawflies for in vivo studies. Reliance on in vivo observations [23] and the potential high levels of NeabNPV environmental contamination and transmission 
$[18,54,56]$ make it difficult to provide exact timing of infection events at both the cytological and molecular levels. Nevertheless, our paper and that of Duffy et al. [23] show that the general features of alphabaculovirus pathology, viral gene expression, replication and $\mathrm{OB}$ production are also present in NeabNPV as one would expect if gammabaculoviruses are ancestral to alphabaculoviruses [1].

\section{Acknowledgments}

This paper was supported through grants to C. J. Lucarotti and D. B. Levin from the Natural Sciences and Engineering Research Council (NSERC) Industrial Research Partnership with industrial partner, Forest Protection Limited (Lincoln, NB, Canada) and the NSERC BioControl Network, and through grants from Natural Resources Canada, Canadian Forest Service to C. J. Lucarotti. The authors gratefully acknowledge Nancy MacAfee for her assistance with the in situ hybridizations, David Thumbi and an anonymous reviewer for critical reviews of the paper, Caroline Simpson for editorial assistance, and the University of New Brunswick EM Unit for the use of their facilities.

\section{References}

[1] J. A. Jehle, G. W. Blissard, B. C. Bonning et al., "On the classification and nomenclature of baculoviruses: a proposal for revision," Archives of Virology, vol. 151, no. 7, pp. 1257-1266, 2006.

[2] J. Thézé, A. Bézier, G. Periquet, J.-M. Drezen, and E. A. Herniou, "Paleozoic origin of insect large dsDNA viruses," Proceedings of the National Acadamy of Science USA, vol. 108, pp. 15931-15935, 2011.

[3] E. A. Herniou, J. A. Olszewski, D. R. O'Reilly, and J. S. Cory, "Ancient coevolution of baculoviruses and their insect hosts," Journal of Virology, vol. 78, no. 7, pp. 3244-3251, 2004.

[4] Y. Wang, R. G. Kleespies, A. M. Huger, and J. A. Jehle, "The genome of Gryllus bimaculatus nudivirus indicates an ancient diversification of baculovirus-related nonoccluded nudiviruses of insects," Journal of Virology, vol. 81, no. 10, pp. 5395-5406, 2007.

[5] Y. Wang and J. A. Jehle, "Nudiviruses and other large, doublestranded circular DNA viruses of invertebrates: new insights on an old topic," Journal of Invertebrate Pathology, vol. 101, no. 3, pp. 187-193, 2009.

[6] Y. Wang, O. R. P. Bininda-Emonds, M. M. Van Oers, J. M. Vlak, and J. A. Jehle, "The genome of Oryctes rhinoceros nudivirus provides novel insight into the evolution of nuclear arthropod-specific large circular double-stranded DNA viruses," Virus Genes, vol. 42, no. 3, pp. 444-456, 2011.

[7] M. W. Gaunt and M. A. Miles, "An insect molecular clock dates the origin of the insects and accords with palaeontological and biogeographic landmarks," Molecular Biology and Evolution, vol. 19, no. 5, pp. 748-761, 2002.

[8] D. Pisani, L. L. Poling, M. Lyons-Weiler, and S. B. Hedges, "The colonization of land by animals: molecular phylogeny and divergence times among arthropods," BMC Biology, vol. 2, article 1, 2004.

[9] D. Grimaldi and M. S. Engel, Evolution of the Insects, Cambridge University Press, New York, NY, USA, 2005.

[10] J. Savard, D. Tautz, S. Richards et al., "Phylogenomic analysis reveals bees and wasps (Hymenoptera) at the base of the radiation of Holometabolous insects," Genome Research, vol. 16, no. 11, pp. 1334-1338, 2006.

[11] B. M. Wiegmann, M. D. Trautwein, J.-W. Kim et al., "Singlecopy nuclear genes resolve the phylogeny of the holometabolous insects," BMC Biology, vol. 7, article 34, 2009.

[12] J. B. Whitfield, "Phylogenetic insights into the evolution of parasitism in Hymenoptera," Advances in Parasitology, vol. 54, pp. 69-100, 2003.

[13] S. M. Farris and S. Schulmeister, "Parasitoidism, not sociality, is associated with the evolution of elaborate mushroom bodies in the brains of hymenopteran insects," Proceedings of the Royal Society B, vol. 278, no. 1707, pp. 940-951, 2011.

[14] D. R. Wallace and J. C. Cunningham, "Diprionid sawflies," in Forest Insect Pests in Canada, J. A. Armstrong and W. G. H. Ives, Eds., pp. 193-232, Natural Resources Canada, Ottawa, Canada, 1995.

[15] C. R. Linnen and B. D. Farrell, "Phylogenetic analysis of nuclear and mitochondrial genes reveals evolutionary relationships and mitochondrial introgression in the sertifer species group of the genus Neodiprion (Hymenoptera: Diprionidae)," Molecular Phylogenetics and Evolution, vol. 48, no. 1, pp. 240-257, 2008.

[16] G. Knerer and C. E. Atwood, "Evolutionary trends in the subsocial sawflies belonging to the Neodiprion abietis complex (Hymenoptera: Tenthredinoidea)," American Zoologist, vol. 12, no. 3, pp. 407-418, 1972.

[17] G. Moreau, "Past and present outbreaks of the balsam fir sawfly in western Newfoundland: an analytical review," Forest Ecology and Management, vol. 221, no. 1-3, pp. 215-219, 2006.

[18] G. Moreau, C. J. Lucarotti, E. G. Kettela et al., "Aerial application of nucleopolyhedrovirus induces decline in increasing and peaking populations of Neodiprion abietis," Biological Control, vol. 33, no. 1, pp. 65-73, 2005.

[19] C. J. Lucarotti, G. Moreau, and E. G. Kettela, "Abietiv-a viral biopesticide for control of the balsam fir sawfly," in Biological Control: A Global Pespective, C. Vincent, M. Goettel, and G. Lazarovits, Eds., pp. 353-361, CABI Publishing, Wallingford, UK, 2007.

[20] C. J. Lucarotti, B. Morin, R. I. Graham, and R. Lapointe, "Production, application, and field performance of Abietv, the balsam fir sawfly nucleopolyhedrovirus," Virologica Sinica, vol. 22, no. 2, pp. 163-172, 2007.

[21] G. Moreau and C. J. Lucarotti, "A brief review of the past use of baculoviruses for the management of eruptive forest defoliators and recent developments on a sawfly virus in Canada," The Forestry Chronicle, vol. 83, no. 1, pp. 105-112, 2007.

[22] S. P. Duffy, A. M. Young, B. Morin, C. J. Lucarotti, B. F. Koop, and D. B. Levin, "Sequence analysis and organization of the Neodiprion abietis nucleopolyhedrovirus genome," Journal of Virology, vol. 80, no. 14, pp. 6952-6963, 2006.

[23] S. P. Duffy, E. M. Becker, B. H. Whittome, C. J. Lucarotti, and D. B. Levin, "In vivo replication kinetics and transcription patterns of the nucleopolyhedrovirus (NeabNPV) of the balsam fir sawfly, Neodiprion abietis," Journal of General Virology, vol. 88, no. 7, pp. 1945-1951, 2007.

[24] F. T. Bird and M. M. Whalen, "Stages in the development of two insect viruses," Canadian Journal of Microbiology, vol. 1, no. 3, pp. 170-174, 1954.

[25] B. A. Federici, "Baculovirus pathogenesis," in The Baculoviruses, L. K. Miller, Ed., pp. 8-59, Plenum Press, New York, NY, USA, 1997.

[26] C. J. Lucarotti, B. H. Whittome-Waygood, and D. B. Levin, "Histology of the larval Neodiprion abietis (Hymenoptera: 
Diprionidae) digestive tract," Psyche, vol. 2011, Article ID 910286, 10 pages, 2011.

[27] W. J. Carroll, Some aspects of the Neodiprion abietis (Harr.) complex in Newfoundland [Ph.D. thesis], State University of Forestry, Syracuse University, Syracuse, NY, USA, 1962.

[28] H. A. M. Lauzon, C. J. Lucarotti, P. J. Krell, Q. Feng, A. Retnakaran, and B. M. Arif, "Sequence and organization of the Neodiprion lecontei nucleopolyhedrovirus genome," Journal of Virology, vol. 78, no. 13, pp. 7023-7035, 2004.

[29] B. A. Moser, J. J. Becnel, S. E. White et al., "Morphological and molecular evidence that Culex nigripalpus baculovirus is an unusual member of the family Baculoviridae," Journal of General Virology, vol. 82, no. 2, pp. 283-297, 2001.

[30] M. A. Bertone, G. W. Courtney, and B. M. Wiegmann, "Phylogenetics and temporal diversification of the earliest true flies (Insecta: Diptera) based on multiple nuclear genes," Systematic Entomology, vol. 33, no. 4, pp. 668-687, 2008.

[31] A. Garcia-Maruniak, J. E. Maruniak, P. M. A. Zanotto et al., "Sequence analysis of the genome of the Neodiprion sertifer nucleopolyhedrovirus," Journal of Virology, vol. 78, no. 13, pp. 7036-7051, 2004.

[32] M. N. Pearson, R. L. Q. Russell, and G. F. Rohrmann, "Characterization of a baculovirus-encoded protein that is associated with infected-cell membranes and budded virions," Virology, vol. 291, no. 1, pp. 22-31, 2001.

[33] M. N. Pearson, C. Groten, and G. F. Rohrmann, "Identification of the Lymantria dispar nucleopolyhedrovirus envelope fusion protein provides evidence for a phylogenetic division of the Baculoviridae," Journal of Virology, vol. 74, no. 13, pp. 6126$6131,2000$.

[34] Z. Liang, X. Zhang, X. Yin, S. Sumei Cao, and F. Xu, "Genomic sequencing and analysis of Clostera anachoreta granulovirus," Archives of Virology, vol. 156, no. 7, pp. 1185-1198, 2011.

[35] S. A. B. Miele, M. J. Garavaglia, M. N. Belaich, and P. D. Ghiringhelli, "Baculovirus: molecular insights on their diversity and conservation," International Journal of Evolutionary Biology, vol. 2011, Article ID 379424, 15 pages, 2011.

[36] C. L. Afonso, E. R. Tulman, Z. Lu et al., "Genome sequence of a baculovirus pathogenic for Culex nigripalpus," Journal of Virology, vol. 75, no. 22, pp. 11157-11165, 2001.

[37] S. M. Thiem, "Baculovirus genes affecting host function," In Vitro Cell and Development, vol. 45, no. 3-4, pp. 111-126, 2009.

[38] C. Detvisitsakun, E. L. Cain, and A. L. Passarelli, "The Autographa californica $\mathrm{M}$ nucleopolyhedrovirus fibroblast growth factor accelerates host mortality," Virology, vol. 365, no. 1, pp. 70-78, 2007.

[39] J. C. Means and A. L. Passarelli, "Viral fibroblast growth factor, matrix metalloproteases, and caspases are associated with enhancing systemic infection by baculoviruses," Proceedings of the National Academy of Sciences of the United States of America, vol. 107, no. 21, pp. 9825-9830, 2010.

[40] A. L. Passarelli, "Barriers to success: how baculoviruses establish efficient systemic infections," Virology, vol. 411, no. 2, pp. 383-392, 2011.

[41] L. S. Lepore, P. R. Roelvink, and R. R. Granados, "Enhancin, the granulosis virus protein that facilitates nucleopolyhedrovirus (NPV) infections, is a metalloprotease," Journal of Invertebrate Pathology, vol. 68, no. 2, pp. 131-140, 1996.

[42] P. Wang and R. R. Granado, "An intestinal mucin is the target substrate for a baculovirus enhancin," Proceedings of the National Academy of Sciences of the United States of America, vol. 94, no. 13, pp. 6977-6982, 1997.
[43] R. F. Chapman, "Structure of the digestive system," in Comprehensive Insect Physiology, Biochemistry, and Pharmacology, G. A. Kerkut and L. L. Gilbert, Eds., pp. 165-211, Pergamon Press, Oxford, UK, 1985.

[44] H. A. M. Lauzon, A. Garcia-Maruniak, P. M. A. Zanotto et al., "Genomic comparison of Neodiprion sertifer and Neodiprion lecontei nucleopolyhedroviruses and identification of potential hymenopteran baculovirus-specific open reading frames," Journal of General Virology, vol. 87, no. 6, pp. 1477-1489, 2006.

[45] N. N. Danial and S. J. Korsmeyer, "Cell death: critical control points," Cell, vol. 116, no. 2, pp. 205-219, 2004.

[46] G. V. Williams and P. Faulkner, "Cytological changes and viral morphogenesis during baculovirus infection," in The Baculoviruses, L. K. Miller, Ed., pp. 61-107, Plenum Press, New York, NY, USA, 1997.

[47] T. Nagamine, Y. Kawasaki, A. Abe, and S. Matsumoto, "Nuclear marginalization of host cell chromatin associated with expansion of two discrete virus-induced subnuclear compartments during baculovirus infection," Journal of Virology, vol. 82, no. 13, pp. 6409-6418, 2008.

[48] B. Arif, S. Escasa, and L. Pavlik, "Biology and genomics of viruses within the genus Gammabaculovirus," Viruses, vol. 3, pp. 2214-2222, 2011.

[49] B. A. Federici and V. M. Stern, "Replication and occlusion of a granulosis virus in larval and adult midgut epithelium of the western grapeleaf skeletonizer, Harrisina brillians," Journal of Invertebrate Pathology, vol. 56, no. 3, pp. 401-414, 1990.

[50] M. M. van Oers, J. T. M. Flipsen, C. B. E. M. Reusken, E. L. Sliwinsky, R. W. Goldback, and J. M. Vlak, "Functional domains of the p10 protein of Autographa californica nuclear polyhedrosis virus," Journal of General Virology, vol. 74, no. 4, pp. 563-574, 1993.

[51] M. M. van Oers, J. T. M. Flipsen, C. B. E. M. Reusken, and J. M. Vlak, "Specificity of baculovirus p10 functions," Virology, vol. 200, no. 2, pp. 513-523, 1994.

[52] D. E. Maxwell, "The comparative internal larval anatomy of sawflies (Hymenoptera: Symphyta)," The Canadian Entomologist, vol. 87, pp. 1-132, 1955.

[53] M. J. Lehane, "The foregut," in Microscopic Anatomy of Invertebrates, F. W. Harrison and M. Locke, Eds., vol. 11 of Insecta, pp. 713-724, Wiley-Liss, New York, NY, USA, 1998.

[54] R. Graves, C. J. Lucarotti, and D. T. Quiring, "Spread of a Gammabaculovirus within larval populations of its natural balsam fir sawfly (Neodiprion abietis) host following its aerial application," Insects, vol. 2012, no. 3, pp. 912-929, 2012.

[55] C. S. Campbell, D. T. Quiring, E. G. Kettela, and C. J. Lucarotti, "Application of balsam fir sawfly nucleopolyhedrovirus against its natural host Neodiprion abietis (Hymenoptera: Diprionidae)," in Proceedings of the IUFRO Workshop on Forest Insect Population Dynamics and Host Influences, pp. 86-89, Kanazawa, Japan, September 2006.

[56] R. Graves, D. T. Quiring, and C. J. Lucarotti, “Transmission of a Gammabaculovirus within cohorts of balsam fir sawfly (Neodiprion abietis) larvae," Insects, vol. 2012, no. 3, 18 pages, 2012.

[57] W. J. Kaupp, “Persistence of Neodiprion sertifer (Hymenoptera: Diprionidae) nuclear polyhedrosis virus on Pinus contorta foliage," The Canadian Entomologist, vol. 115, pp. 869-873, 1983. 

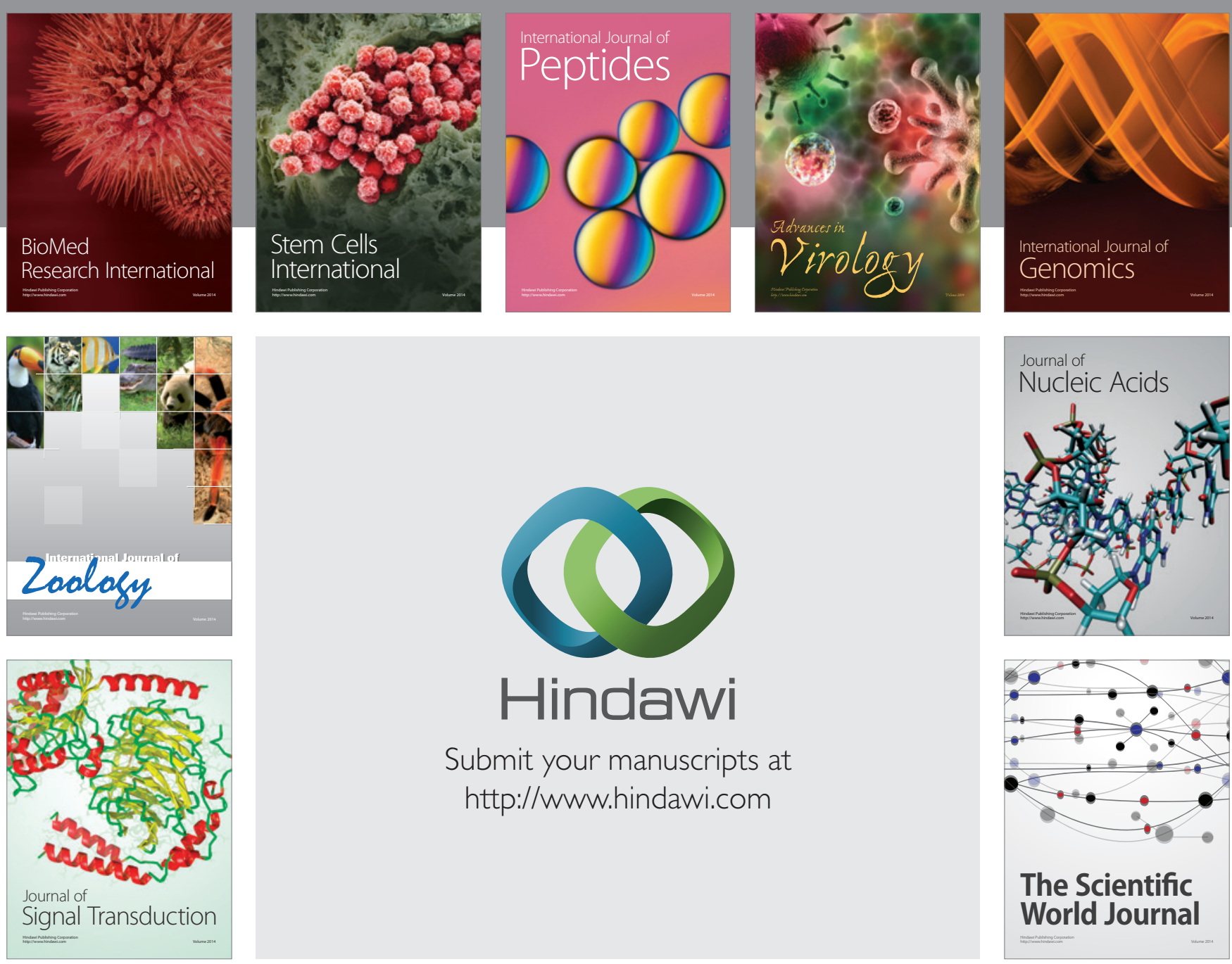

Submit your manuscripts at

http://www.hindawi.com
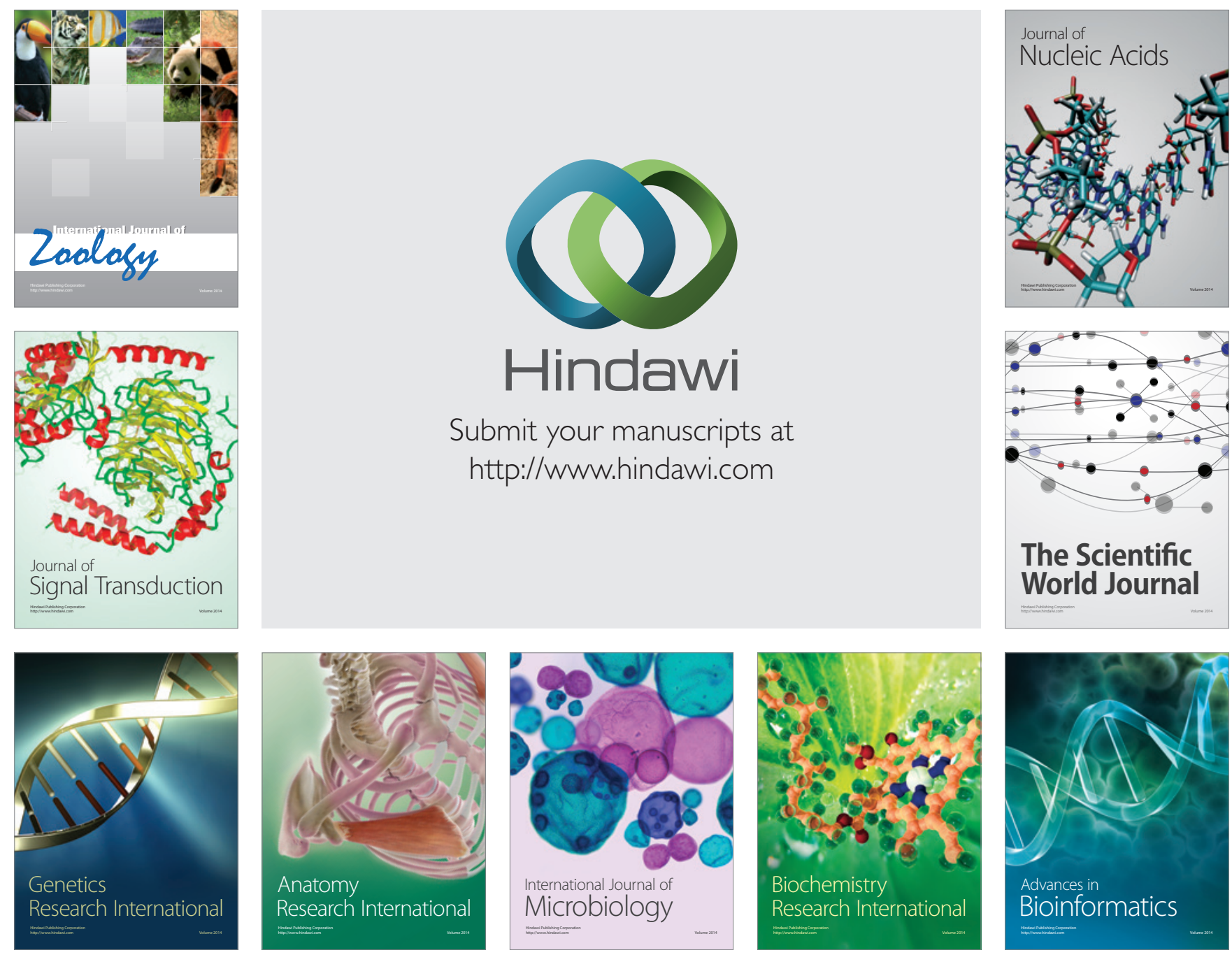

The Scientific World Journal
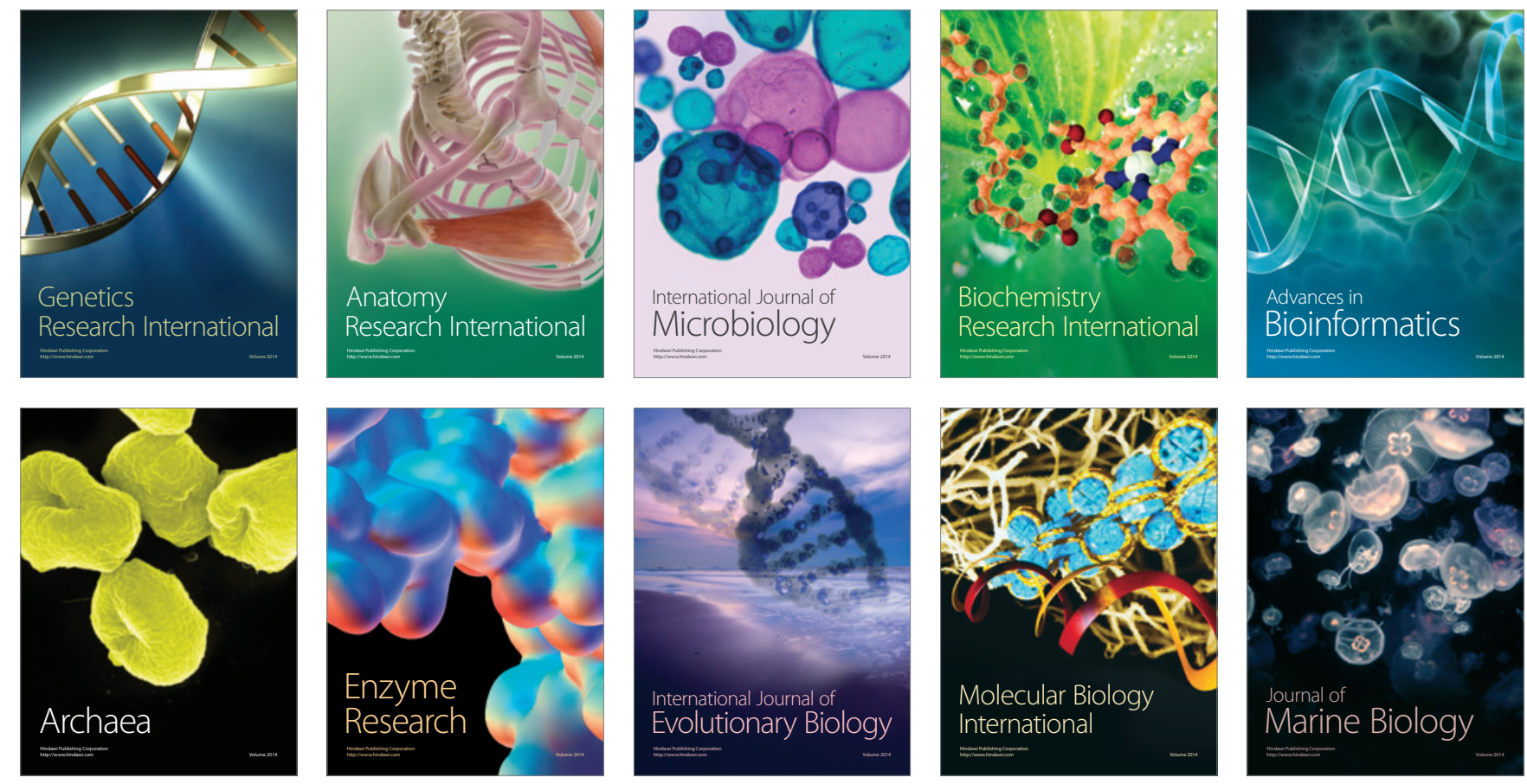